\title{
Media Development in Syria: the Janus-Faced Nature of Foreign Aid Assistance
}

BILLIE JEANNE BROWNLEE

ESRC Postdoctoral Fellow, Institute of Arab and Islamic Studies, University of Exeter, UK ${ }^{*}$

\begin{abstract}
This article intends to provide responses to some of the many unanswered questions about the making and the transformation of the uprising in Syria by exploring a new avenue of research: media development aid. Most of the academic interest has been oriented towards the role that the new media played at the time of the uprising, insufficient interest, instead, has been directed to the development of the sector in the years predating it. What emerges from this article is that the Syrian media landscape was strongly supported by international development aid during the years prior the outbreak of the uprising of 2011. By looking at the complex structure of media aid architecture and investigating into the practices and programs implemented by some representative organisations, this article reflects on the field of media development as a new modus operandi of the West (EU and US especially), to promote democracy through alternative and non-collateral bottomup support.
\end{abstract}

Key words: Syria, uprising, activism, social media, media development, foreign aid assistance

Nearly six years have passed since the political uprising that swept through many Arab countries began. Syria was caught in the grip of this revolutionary moment, one that drove the country to a civil war with no apparent way out. Analysts advanced a number of theoretical explanations for this event, which included the demographic profile of the young generations and the economic difficulties they experienced, corruption of the government, the use of techniques from successful campaigns and the coordination of dissent through traditional/offline and new/online forms of contention. The employment of the new media by anti and pro-government groups have reached an unthinkable scale, to the point that the media have become instruments not limited to the purpose of informing, planning and coordinating the protest, but 'performing' in the conflict,

\footnotetext{
${ }^{*}$ Correspondence address: Billie Jeanne Brownlee, 22 Tyndale Road, OX4 1JL, Oxford, UK. E-mail: bjb205@exeter.ac.uk.
} 
exacerbating the fight, instilling fear in the enemy and intimidating the adversary, while proselyting. By going beyond the dichotomy that frames the media as a deus ex-machina of the uprising or conversely, as a means of its expression, this paper attempts to draw attention on the leverage and role that West's media aid assistance had in fostering popular mobilization in Syria and to many extents, the rest of the region. Indeed, within the greater debate around the roots of what has been called the 'Arab Spring', very little attention has indeed been given to the change of the media scene in the years that predated the outbreak of the uprising and in specific to the role of international aid assistance to the media sector.

The phenomenon of media aid industry in Syria as much as in other geographical contexts has never generated extensive academic interests. Interestingly, if literature on media development can be defined as nascent at its very best, its practice marked what has been Western foreign policy programs since the second War World (Colle, 2002). ${ }^{1}$ Communication and information technologies have always been considered having beneficial effects on democracy promotion and economic development of developing countries, based on the assumption that the more citizens are empowered to make informed choices, the better the media serve democracy (Sakr, 2004). ${ }^{2}$ However, foreign aid investment in the media sector has seen a visible investment in the past decade given the potentials that the new information and communication technologies of the last generation seem to offer in terms of interrupting the state's monopoly over the means of information and offering citizens' empowerment in contexts unfavourable to democratic values (Hoffer, 2002). 3 This type of Western support has proved pivotal in mobilising populations to overthrow repressive regimes in Georgia, Kyrgyzstan, Ukraine and Lebanon, only to mention a few (Kumar, 2006). 4 Today Western governments are investing huge sums in media projects in Arab countries, to the point that, as Bruce Stanely holds, such intervention has become an industry (Stanely, 2007)..$^{5}$ In this regard, not enough rigorous research and scholarship exists about the integration of new media and information assistance by development actors (EU countries and US) as part of their democracy promotion programmes implemented in perspective democracies. This type of analysis is, to a greatextent, inexistent concerning the Middle East, despite the added value it would offer to the understanding of the causes that brought to the turbulent events of 2011.

By looking at the media aid architecture in Syria, this paper investigates into the role and praxis of a number of donors and contractors that intervened in the country. The article consists of two parts. The first, more descriptive, intends at framing the concept of media development within the wider literature and understanding the way it has been implemented in other historical periods and geographical frameworks. The second part, more analytical, focuses on Syria's media aid architecture, the actors involved, the projects that have been implemented and the impact this mechanism produces on a rather closed society like Syria. Ultimately, the chapter attempts to locate this issue within the broader and unfinished debate about the role and effects of international assistance in fragile contexts where humanitarianism and development are not simply conveying international altruism but at times favouring political ends. 


\section{Defining Media development}

Before getting into the analysis of the media aid industry in pre-revolutionary Syria, it would be appropriate to dwell on the concept and significance of media development. The Centre for International Media Assistance (CIMA) refers to the term 'media development' to indicate the efforts by organisations, people and governments to develop the capacity and quality of the media sector within a specific country or region. ${ }^{6}$ The actors engaged in this field can range from governments, to multilateral organisations and large number of national and international non-governmental organisations (NGOs). In general, these actors are classified in two categories: donors, referring to those who provide funding and intermediaries, indicating those organisations that design and implement projects, often in cooperation with local partners in the recipient country.

As earlier mentioned, in the past 20 years, the expenditure in media development assistance by Western agencies has skyrocketed, reaching an estimated \$ 645 million in 2010 (Nelson, Pena, 2012). 7 The increase investment in the sector has occurred in concomitance or as an effect of the emergence of the new media technologies, which have proved meeting the needs and requests of international actors better than what had been with traditional ones. The promotion of free and independent media around the world takes many forms: journalist training and education; improving the legal environment for media; funding new media outlets or improving existing ones; media literacy training, digital and cyber-security training; infrastructure development. ${ }^{8}$

Media development projects are often difficult to investigate as organizations supporting media projects very often do not have a separate office or division in charge of media development portfolio, including media assistance under broader headings, such as 'democracy and governance', 'capacity building', 'human rights' or 'civil society' (i.e. European Commission). In the words of Eric Newton, senior adviser at the Knight Foundation, supporting media assistance aid is far more important than supporting a vaccination's campaign, as 'you can't get the vaccine in someone's mouth until you get in that someone's head the idea that the vaccine is good for you' (Moller, 2009). ${ }^{9}$ Therefore, funding media projects becomes a means to face the problem from its roots, by creating the conditions for the solution of the problem from within, with no direct external intervention, at least not formally. When applied to developing countries with non-democratic institutions, the promotion of media literacy acts as a tool to make better informed citizens, who can pressure governments to become accountable and to uproot corruption. Under these conditions, media development becomes a means soft power, according to Nye's definition as the ability to attract and co-opt rather than coerce, as a means of persuasion, through intangible means like culture, values and institutions of politics. ${ }^{10}$ 


\subsection{Media development assistance in the Middle East}

The West's promotion of media development assistance in the Middle East is not a newly adopted policy but a concept, albeit differently, that dates back to the Cold War era, when the Middle East had been transformed into a confrontational battle ground between the United States and the USSR, a reality (alas!) not that far from the present time. The two superpowers were fighting to win the hearts and the minds of the 'new nations' of the postcolonial world by providing them with modernisation projects (Shah, 2011). ${ }^{11}$ Both states mostly adopted two tactics: the provision of development aid and the competition of the airwaves: Radio Moscow versus Voice of America (VOA). To ensure greater success, in 1949 VOA commissioned an empirical research to be conducted in Turkey, Syria, Iraq, Lebanon and Iran on people's radio-listening habits (Matar, Bessaiso 2012). ${ }^{12}$ The paradigm of 'communications and development' was first enounced in this research and then extensively explained by one of the researchers Daniel Lerner, in his contentious volume The Passing of Traditional Society (1958). ${ }^{13}$ The book, ingrained in an Orientalist approach, developed the idea of employing the media to 'modernising' societies through a top-down or more accurately 'outsidein' approach. Despite the numerous critiques in the academic community towards the 'patriarchal, xenophobic and simplistic character' of this model of social change, de facto, this model still persists in Western (US and EU) development discourse. ${ }^{14}$ The geopolitical controversies of the Cold War and post-Cold War period, the industrialised 'North' and the developing 'South' found place in the concept of a 'new world information and communication order', intended to set a frame on the media's role in society and the world at large (Mosco, 2009). ${ }^{15}$

Yet its idea carried over to the new millennium, embedded in the agenda of Western politics towards the Middle East. Indeed, in the aftermath of the 9/11 terrorist attacks and the growing concern of the international community of the alarm represented by 'fragile states', democracy assistance received new incentive as a means of the international community to counterbalance the threat and push for democratic transitions. Military intervention in Afghanistan and Iraq had once again, proved unsuccessful and what was worse, counterproductive, nourishing more hatred towards the West and favouring the increase of terrorism (Sakr, 2006). ${ }^{16}$ Therefore, the international community became more aware of the need to develop new strategies of democracy promotion, which could engage and build partnership with non-governmental Arab groups and local citizens and build links across Middle Eastern countries. ${ }^{17}$

Today the two largest providers of democracy assistance are the United States Agency for International Development (USAID) and the European Commission (EC). ${ }^{18}$ The principal areas of democracy building that the West has been engaging with in the Middle East are elections and electoral processes; political parties; judicial reforms; civil society and the media. At the core of these programmes, there is a common intent to raise people's communication and information literacy, which are considered to be at the base of any regime change. 


\section{Syria's Media Aid Architecture}

Looking at the media aid industry in Syria, opens a new avenue to the study of the role and purpose of media assistance programs in a country that witnessed a wide-scale popular uprising in 2011 and which heavily relied on the use of new media. This article examines the impact of media assistance projects in Syria under the presidency of Bashar al-Asad, which coincided with a period of great changes for Syria, given the reforms carried out by the new president, the new agreements signed with foreign countries, the establishment of a private sector, the spread of satellite dishes and Internet connections and, most importantly, a population of young people, increasingly educated and yet underemployed who could become fruitful resources in whom to invest. ${ }^{19}$ This dynamic and yet vulnerable political system, created the right conditions for foreign investment in the media sector, with the intent of raising the country's media literacy and empower local civil society actors.

According to the Directory of Development Organizations, in 2011 a total of 107 development organisations operated in Syria, consisting of international organizations, government institutions, private sector support organisations (including fair-trade), finance institutions, training and research centres, civil society organisations, developing consulting firms and information providers. However, the actual number of actors involved in development programmes was higher, given the often-unofficial way to operate that many organisations adopted in the Syrian context. For instance, media development programmes have often opted for non-government approved ways to perform in Syria, on the basis that the field of operation was too sensitive and risky. Despite the openings that the newly elected president Bashar al-Asad promoted at the start of his presidency, the regime kept a strict control both over foreign funding and over organisations working in the development sector. The main tactic adopted by the regime to control the work of civil society organisations was to perform as principal promoter and funder of these organisations, a cunning expedient to reinvigorate the regime's image abroad and at home, while also guaranteeing monitoring of these organisations' activities. In these circumstances, donors had two possible options to operate in Syria: one official, with the regime's approval and one unofficial, more difficult to realise, which consisted in having to operate underground, on-line or by training Syrians abroad (Taki, 2012). ${ }^{20}$

The aid structure through which media development programmes are put in place is a complex mechanism that varies according to the specific case. A simplified version (Figure 1) of this structure would be organised in terms of structure and level of participation (Price, Noll, De Luce, 2002).21

In this graphic, the flow of funds comes from donors (rich governments or individuals), it then reaches agencies (multilateral institutions), and it is at this point funnelled to the recipient country through the implementers (NGOs, local partners, etc.). ${ }^{22}$ The standard map includes donors and donees, governments, quasi-governmental organisations and NGOs, funders, intermediaries, local partners. Some actors participate in more than one stage. 
This scheme is only partially respected, as there are numerous private sector groups engaged in aid, both as donors and as implementers of non-governmental organisations. In addition, if the recipient country is an authoritarian state, as in the case of Syria, it may hamper activities that appear politicised or viewed as jeopardising its stability. In this case, some organisations resort to a ploy to dupe the regime's restrictions, by working behind the backs of governments, implementing projects underground, on-line or working with citizens (Syrian diaspora) outside their national borders.

\subsection{Donors}

The analysis of Syria's media aid architecture might not exactly appear intriguing if it is limited to presenting the profile of specific actors, without examining the projects funded and with them, the effects they produce. For this reason, this paper opts to limit the analysis to the two main donors involved in Syria's media aid architecture, underlining the specific area of competence and operation, while leaving more space to the analysis of the projects implemented by a number of organisations in the years under study.

Support for independent media is the main field of action of the European Commission (EC) and the US Agency for International Development (USAID). Both agencies are famously known for the byzantine and often intricate, if not obscure structure of their organisation, which makes at times very difficult any attempt to track specific projects or funding. Media development projects are particularly difficult to track, as they are scattered across different sectors and funding instruments. It is rather emblematic that media aid programmes, which are aimed at enhancing freedom of expression and transparency, are at times so obscure and secretive.

The EC and USAID have implemented media assistance programmes directed at developing independent press and broadcasting, strengthening the professionalization of media producers and outlets, supporting reform of the media legislation, establishing networks of information and interregional exchange of information on human rights. However, the media sector has not been the main recipient of assistance or the target of development programmes, but rather the vehicle to achieve far-reaching goals such as to increase citizens' participation in politics, strengthen the respect of human rights and democratise institutions. In fact, media development projects fall under the voice of broader sectors such as 'social development and democratisation', 'civil society', 'human rights and democracy'. Interestingly, both organisations have increased their investment in media assistance programmes, with a noticeable shift towards the Middle East in the past decade. In particular, USAID has a long history of investing in media assistance programmes, with a focus on Latin American countries in the 1980s, which has then shifted to Eastern Europe and Eurasia after the fall of the Berlin Wall, and that has ultimately reached the Middle East in the past decade (Price, Noll, De Luce, 2002). ${ }^{23}$ 
The EU's instrument regulating economic and financial cooperation with Europe's fringes, in North Africa and the Middle East, is the European Neighbourhood and Partnership Instrument (ENPI), which for the period 2007-2013, was assigned 12 billion Euros. Raniero Leto, EU functionary for the Directorate General of Develoment and Cooperation, argues that media assistance programmes in Syria were aimed at the production, broadcasting and distribution of new and existing television and radio programmes and the distribution of Internet-based media products; training programmes provided by the European Neighbourhood Journalism network; establishing of online networks between media producers; producing of audio-visual products promoting intercultural dialogue. ${ }^{24}$

Similarly, USAID's assistance projects, including media development, are implemented under four main regional departments: Africa, Latin American and the Caribbean, Europe and Eurasia, and Asia Near East. Hence, media development programmes are supported through the specific geographical department, as well as by other channels, like the State Department Bureaus. USAID’s spending on media development in the Middle East shot up in 2008 from $\$ 1$ million to more than $\$$ 42 million in a single year (Cary, D’Amour, 2013). ${ }^{25}$ In Syria, given the restrictions imposed by the regime and the not ideal relations with the US administration before 2011, USAID has only been able to intervene indirectly through programmes supporting nascent civil society groups and actors that promoted independent media by providing training, overseas travel grants and scholarships to local civil society actors. Among the numerous governmental instruments designed by the State Department to fund grassroots and bottom-up initiatives of civil society groups in the Middle East and North Africa, one should mention the Middle East Partnership Initiative (MEPI). ${ }^{26}$ The name of the Middle East Partnership Initiative (MEPI) was recently linked to Syria with the release of the WikiLeaks' cables on US secret backing of Syrian opposition groups before the outbreak of the uprising in 2011 (Whitlock, 2011). ${ }^{27}$ According to the released documents, the MEPI was transformed into the main channel to destabilise the Syrian regime under the name of civil society support programmes. While Edgar Vasquez, a State Department spokesperson, said that MEPI had allocated USD 7.5 million for Syrian programmes since 2005, the WikiLeaks cable pegged a higher amount of USD 12 million between 2005 and 2010. In particular, the cable held that US funding had been allocated to start up an anti-Assad satellite channel, Barada TV. Barada TV's director, Malik alAbdeh, whom I interviewed, denied any affiliation to US funding, though he declined to share the names of those independent Syrian businesspersons who, he held, had sponsored the channel. ${ }^{28}$ The 24 hours channel, not on-air anymore, became very popular among the Syrian regime opposition viewers, with its shows, like 'Toward change' - a panel discussion on current events -, and 'First Step' - a programme produced by Syrian dissident group based in the US - progressively becoming reference for many antagonists of the regime. 


\subsubsection{BBC Media Action}

The BBC Media Action represents an important player in the field of media development in Syria. Despite the high level of competence and successful history of international media assistance, Syria has not been an easy ground to work, given the regime's tight supervision and the suspicion overlooking any foreign activity.

The BBC Media Action has been among the pioneer organisations implementing media assistance programmes in Syria. Juliette Harkin, BBC journalist and specialist of Syrian media, affirmed in our first interview that Syria was selected, among other seven Middle Eastern countries, for a $£ 1.5$ million package project between 2004 and 2007. ${ }^{29}$ The project, Arab Media Dialogue programme, consisted in building partnerships with Arab media organisations and training management and staff of media agencies. ${ }^{30}$ Harkin, project manager of the programme and based in Damascus at the time, said that the programme in Syria consisted in the organisation of trainings in journalism skills, business and management for selected journalists, editors and managers, working in partnership with both state and private media outlets.

In 2006, the BBC directed its support to a newly-created private online newspaper, Syria News, by training its managers on sustainable business models for online news and by organising tailored BBC-run workshops for seven of its staff. Part of the team was selected to take part in business development training and in study courses in London. In turn, Syria News became a role model in the field of professional media outlet in Syria, working with high international journalistic standards that provided practical training scholarships and materials to graduate students from the journalism department at Damascus University. This means that the training acquired in the first place by the BBC Media Action was then transferred to the Syria News staff and to the graduate students in journalism who underwent a stage at the newspaper headquarters.

Of a different nature was the three-year project 'Socially Responsible Media Platforms in the Arab World' that the BBC launched in 2008, with the aim of setting up an interactive online training platform for Syrian journalists and bloggers. The project, the Ara2 (in Arabic for 'opinions') Academy, directed by Maha Taki, was thought of as a tool capable of bridging this gap and making the Syrian bloggers and journalists' community stronger. Based on the already existing BBC on-line media training model, though targeting the whole Arab world, the Ara2 Academy became an on-line training platform, in Arabic, targeting only Syrian journalists and bloggers. Taki sustained that, under president Bashar, both journalists and bloggers had tried to make small changes by opening news spaces on-line, whether in the form of a magazine or of a blog, but with no attempt at connecting these two worlds, which remained completely separate. Conversely, the Ara2 Academy tried to create a link between these two worlds, bring them closer, make them know each other and make them interact. The project developed through two courses, 'Basic Journalism Skills' and 'Social Media Tools', based on basic journalists and bloggers' skills like how to open a blog, how to upload 
videos, how to interact, how to write news pieces, how to use Twitter and other aggregators. By doing so, bloggers and journalists would learn each other's skills and fields of competence and interact in the production of news. With no official advertisement of the course, the programme managed to train, by word of mouth, over 75 men and women among whom there were journalists, bloggers and web masters before the worsening of the political situation in 2011, which led to an inevitable freeze of all development aid. ${ }^{31}$ For this reason, many NGOs have preferred to train journalists rather than build local institutions, which requires overcoming more obstacles, like the regime control or justifying their presence in the country.

The deteriorating reality in Syria, with a popular uprising turning into a civil conflict, obliged many international organisations to freeze their programmes. This was the case for the BBC Media Action, which with the increase of violence in Syria, decided to step aside for some time, feeling, in the words of Taki, very nervous of any involvement in such circumstances. When it became clear that the Syrian conflict was far from ending anytime soon, the BBC Media Action decided to change the nature of its projects, the targets and the location of its trainings. This means that media assistance projects have tried to meet the information needs of the refugees inside and outside refugee camps, offer practical advice and restore values of peace and solidarity forgotten during the conflict. ${ }^{2}$

\subsubsection{The Institute for War and Peace Reporting}

The Institute for War and Peace Reporting (IWPR) is one of the main institutions involved in media development, working in frontlines, crises and transition areas around the world. IWPR has a long and varied experience across the world, having started its mandate in the Middle East after the war in Iraq of 2003.

According to the manager of IWPR's MENA programme Susanne Fischer, interviewed in Beirut, their strategy in Syria has been, in primis, to educate a new generation of journalists. 33 'The University curricula (the national one) had nothing to do with what we, the West, meant for journalism', held Fischer. Decades of authoritarian ruling had transformed the field of journalism into an extension of the ministry of information and journalists into state's functionaries.34 IWPR was one of the few organisations, like BBC and Deutche Welle, which started working in Syria long before the outbreak of the uprising in 2011, with the intent of nourishing young journalists with new values and skills. Conversely to the modus operandi of BBC and Deutche Welle, which operated with the state's approval, IWPR worked undercover. In both cases, meaning working with and without state's authorization had its limits. In fact, having to work undercover requires more time for projects to take off, for networks to be created and mostly to gain people's trust; while working under the state's authorisation means less freedom in programmes' planning.

The organisation became officially active in the country in 2007, when it hosted a first round of media training in Istanbul. The training was offered to journalists and media activists belonging 
to three different groups: a Kurdish group, a group in opposition to the regime and a mixed one (ethnically and politically speaking). These first trainings, Fischer asserted, were a primary way to assess the general media literacy level in Syria, draw a profile of Syrian journalists-activists and tailor future trainings according to their specific needs. From 2008, IWPR became operative in Syria, working with a local partner, the Syrian International Academy for Training and Development (SIA), which became the basis for their practical trainings. 35 The Syrian International Academy was a Damascus-based institution, which offered specialised training and development in the fields of Media, Public Relations and International Affairs and Diplomatic studies. In particular, the Department for Media Training employed elite experts, specialists and trainers from partners like Al-Jazeera Media Training Centre in Qatar and Radio Monte Carlo, providing well-equipped facilities which suited any media courses and activities. IWPR's MENA manager, had found in the director of the Syrian Academy, a private institute, an open-minded person, willing to offer new curricula to Syrian journalists, even if this might not always coincide with the regime's views.

The trainings organised by IWPR were not a one-day shot, but intensive one-week or more training sessions. They would not finish on the last day of the training, on the contrary 'the actual training would start at the end, when the trainees made their first steps as media professionals, shadowed by their trainers'. This meant that IWPR's trainings persisted over time, with a mentoring that continued at distance. For this purpose, IWPR established two news website, The Damascus Bureau and CyberArabs, to assist their trainees beyond the training. The Damascus Bureau was thought of as an open window to Syrian issues and beyond, tackling prominent political, economic and cultural news. Rather than covering breaking news, the website presents in-depth coverage of issues related to civil society, refugees, human rights, justice and more recently the dire reality of the Syrian conflict. ${ }^{6}$ The CyberArabs website instead addresses a wider audience, targeting issues of cyber security and delivering up-to date information on the latest digital security threats.37 In 2010, the regime imposed strict surveillance on suspicious activities, limiting progressively the operational activity of organisations like IWPR. Under the ultimatum of the regime, IWPR decided to re-locate to Beirut and set up its trainings from there. According to Fischer, the regime had been aware of their activities before 2010, but it somehow tolerated their presence, seen as non-hazardous. Indeed, most of the articles that the trainees wrote had been intentionally uploaded on-line in English (whether they were written in English in the first place or translated afterwards), in order to draw less attention and fuel less hatred from the government. Despite this shrewdness, the often politicised stances that some of the articles acquired, especially when covering human rights issues, made the government issue a clear and definitive red light signal.

IWPR had a dominant role in the field of media development in pre-revolutionary Syria. Media trainings ranged from classes on basic journalism, print and on-line journalism, as well as video journalism; they became increasingly sophisticated and tailored with the advancement of the programmes and with groups that were called for a second round. The organisation trained around 80 Syrian journalists between 2007 and 2010, with a selection of profiles that were not specifically 
media-related, but who came from different occupations, though all motivated to learn how to use the new media.

Since the outbreak of the uprising, IWPR has been very cautious with its operation, relocating all the trainings to Lebanon (Beirut), Turkey (Istanbul and Gaziantep)and only recently in the Syria's liberated areas.

\subsubsection{Arab Reports for Investigative Journalism}

Arab Reporters for Investigative Journalism (ARIJ) is the first and only non-profit organisation in the region dedicated to promoting investigative journalism. The Amman-based organization was established in 2005 to support independent quality professional journalism, through in-depth journalism projects, and offering media coaching. '38 The organisation has been working in the field of print, radio, TV and on-line media in Jordan, Syria, Lebanon, Egypt, Iraq, Bahrain, Palestine, Yemen and Tunisia. ARIJ was set up as the outcome of a number meetings held by Arab journalists, editors, media activists and professions who came together, committed to enhance the quality of Arab journalism. ${ }^{39}$ The main line of the organisation is to train journalists in investigative journalism and support their specific investigative reports, funding their travel costs, access to national and international databases, translate their reports and what is more providing legal support if action is taken against a journalists.

Saad Hattar, head of the Investigative Reporting Department at ARIJ, with more than 20 years of experience as a media trainer, taught media trainings to more than 1,200 journalists in the region, of which around 150 Syrians since its opening. $4^{\circ}$ ARIJ, explained Hattar, had been working in Syria in an official way, the only way, he held, to work effectively in Syria, without jeopardising those participating. By having the regime's consent, ARIJ has been able to offer trainings to both private and state-sector journalists through their offices in Damascus and Aleppo, with some fieldtrips to their headquarters in Amman. ARIJ has been able to gain the regime's blessing in the name of the new type of journalism that it promotes, investigative reporting, presented to the Syrian government as an experimental field that, albeit not encompassing political issues, it can support the government with keeping track of cases of social mismanagement and corruption. Nonetheless, Hattar admits that given the often weak professional profile of some of their Syrian journalists, ARIJ has actually carried out trainings that were not focused only on investigative reporting but they more broadly encompassed more general knowledge on how to write a news story, how to use online databases to dig for accurate information and how to make use of social-media and how to produce video reporting.

The legal support offered by the organisation constitutes a precious factor for many journalists in Syria, who have this far been strongly limited by a mechanism of self-censorship, fearing to overstep redlines. Rana Sabbagh-Gargour, ARIJ executive director, stressed that ARIJ's trainings 
were and are not political, 'our ultimate goal is to teach a new, professional technique that journalists can apply to any issue that they deem to be of public concern'. ${ }^{41}$ In fact, most investigative reports that Syrian journalists have published, through ARIJ, have covered issues affecting the lives of the Syrian public, like an increase in child sexual abuse, public health risks from environmental waste to illnesses due to family inter-marriages or the increase number of women working in the private sector with no social insurance. Hattar explained that Syrian journalists have been offered weekly trainings, workshops at their headquarters in Amman and one-to-one mentoring and continual supervision of investigations..$^{2}$ In return, those trained had to spend extensive hours on investigative fieldwork, which included anything from interviews, archival research and data collection, all of which required their steadfastness to overcome bureaucratic obstacles limiting access to information.

ARIJ has been carrying out impressive work that is not just introducing a new type of journalism, a novelty in the region, but it is trying the update the Arab educational system, which is outdated and which has produced a largely apolitical, a-critical thinking generation. ARIJ has not stopped working since the outbreak of the Arab revolts and despite the hardships that the present political unrest has brought, investigative journalism seems to be gaining more ground as a tool to investigate and disclose recent cases of money laundering, political corruption and organised crime (Bajec, 2012).43

\section{Conclusion}

Remarking upon what was said at the beginning of this article, this study presents a glimpse of a sector that is understudied and provides a new tile in the mosaic of the Syrian pre-uprising decade and to the many unanswered questions regarding the seeds of the popular revolts. This study argues that the Syrian uprising broke out as an effect of a number of contextual factors, among which the expansion of the Syrian media landscape played a dominant role. The growth of the sector resulted as an effect of the country's opening to the new media technologies and to modest institutional reforms affecting the sector, but also as a result of foreign aid projects. Media assistance projects contributed to the improvement of the media sector, supporting newly established media outlets, reforming existing ones, expanding social media use, improving the quality and quantity of news, as well as journalists' professionalism. What is more telling, media development positively affected civil society activism, empowering new civil actors in the use of new technologies to push the government's red lines further, to explore the information horizon offered by the Internet and to transform the online space in platforms to reclaim their rights and get involved in civil and political issues. The effects produced by media assistance projects were most probably beyond the implementers' expectations and the projects' objectives. Yet, the media aid industry found a particular favourable astral moment during the presidency of Bashar al-Asad. In fact, the president 
had proved to be more inclined to open a dialogue with Western countries, within limits, aware that compromise had to be signed in order to avoid an Iraq-style scenario. On the other hand the US shifted its strategy from military confrontation to smart means for leverage, among which new media occupied a most prominent role.

Initially, media assistance projects did not produce immediate, far-reaching results. In this sense, Maan Adul Salam, the owner of Etana Press - an online portal on women's issues funded by a variety of international organizations - argued that the Internet provided a window to the world, but did not make any change at the end (Eisenlohr, Cavatorta, 2012).44 However, the empirical evidence from Syria demonstrates how, with time, the cyberspace 'activated' citizens, producing an important counter-discourse to the regime's official one. The effect of media assistance aid did not reflect on the whole society, but only on a minority directly involved in the media trainings, whether as journalists, activists or institutions. However, this minority played a decisive role in connecting with ordinary citizens off-line, stimulating civic awareness and political participation and creating a fertile terrain that could be exploited for off-line mobilisation at the right time.

This assertion entails that the West's foreign aid investment is not driven by development aims exclusively, but by broader political aims, among which to destabilize unfriendly regimes account for a strategic one. Syria burst into a revolt before this policy was uncovered. However, in countries like Cuba, these techniques have been short-lived. The multi-million dollar program of USAID, disguised as humanitarian aid, established an anti-regime social-network called ZunZuneo designed to spark political dissent. The attempt failed when the authorities discovered about it in early 2014.45 Interestingly, now that the Cuban and US administration have seen a historic rapprochement, US's attempts to destabilize the Castro's regime through media development projects, like Radio and TV Martì, broadcasting from Miami since the late 8os, are now scrambling to stay relevant as the relationship between the two countries is showing signs of improvement. 46

The denial of media assistance programmes by international agencies and Western governments does not hold water in Syria, as well as for the rest of the region. The high numbers of activists and journalists trained by international organisations are a clear proof of this multifaceted strategy. A well-known Tunisian blogger, Ben Gharbia complained in September 2010 about the role of Western governments using digital activists to achieve their geopolitical goals and foment unrest. He affirmed that Western funding programmes were the 'kiss of death' for Arab activists, as their anti-regime activities would sooner or later put their life in danger and the support that Western governments had offered them would dissipate. As Rolf Paasch of Friedrich Ebert Foundation stated, 'I personally find it very problematic to use journalists to drive an agenda. There is a value in journalism in and of itself. If I use the media to drive my agenda, the government can do the same. It's actually a bad precedent' (Alcorn, 2011). ${ }^{47}$

Rami Nakhle, a well-known Syrian activist who became one of the spokesmen of the Syrian revolution, was able to escape from the pitchfork of the regime and move to Beirut and then off to the US. $4^{8}$ Nakhle represents the example of a Syrian activist, who with IT knowledge and curiosity, 
was trained by a number of media organisations, including the Institute for War and Peace Reporting and Freedom House in Syria and abroad (Lebanon, Jordan, US) and who later became a trainer for other Syrian activists. ${ }^{49}$ In his words, his first encounter with the Internet in 2006 and the first 72 hours he spent surfing the web, represented the 'crossing of the bridge from darkness to light', after that 'I started questioning the information I had been fed with at school, on TV, from religious leaders and also my family... I realised how we had been brain-washed by the regime'. Nakhle received trainings on news writing, social media, digital security and leadership, becoming active in Syria as well as in the region, through networks of Arab activists. He later became a trainer himself for other Syrian activists and funded the online campaign 'Get Your Rights', to help Syrians circumvent Internet censorship, which reached 900 followers in 2009 and the 'Enough Silence Campaign' that called for the lifting of the Emergency Law and the release of political prisoners. As he affirmed, every time he would teach another Syrian how to use the Internet and the many possibilities this tool offered, another man "would cross that bridge from darkness to light and that is the foundation of the Arab Spring'. With these words, Nakhle unconsciously said something that echoed one of the first speeches of Bashar al-Asad - himself an IT-savvy - when he said, 'I have always seen the problems caused by chaos and corruption, and these problems can be fought with the computer. And if you see a computer, you must be organized, and you cannot be chaotic and be good with a computer. The technology was created to make things easier and faster, and we need to make things easier and faster in this country' (Eisenlohr, 2011).50 


\section{Bibliography}

Alcorn, James, Chen, Amy, Gardner, Emma, Matsumoto, Hiro, 'Mapping Donor Decision Making on Media Development', Paper by Internews, World Bank Institute, May 2011.

Alvarez, Lizette, 'Radio and TV Martì, US broadcasters to Cuba, emerge from Cold War Past Facing Uneasy Future', The Huffington Post, March 24, 2015.

Bajec, Alessandra, 'How to practise investigative journalism in the Arab region', EMAJ, March 16, 2012.

Cary, Peter, D’Amour, Rosmary, 'US Government Funding for Media: Trends and Strategies', CIMA, March 19, 2013.

Colle, Royal, 'Threads of Development Communication' in Approaches to Development Communication, Jan Servaes ed., UNESCO, Paris, 2002, 137-177.

Halberg, Peter-Bastian, 'Filling the Information Vacuum for Syrian Refugees', UNHCR, January 20, 2014.

Harkin, Juliette 'A Reappraisal of the Practise of Journalism in Contemporary Syria', unpublished MPhil thesis, Oxford University, 2008.

Kedizie, Christopher, Aragon, Janni 'Coincident Revolutions and the Dictator's Dilemma' in Technology, Development and Democracy, Allison, Juliann ed., New York: State University of New York, 2002.

Kharas, Homi, 'Trends and Issues in Development Aid', Working Paper 1, Wolfensohn Center for Development,

Brooking Institute, November 2007.

Kumar, Krishna, Promoting Independent Media, Boulder: Lynne Rienner, 2006.

Lerner, Daniel, Pevsner, Lucille, The Passing of Traditional Society: Modernizing the Middle East, Glencoe: The Free Press, 1958.

Lewis, Paul, Roberts, Dan, 'White House denies “Cuban Twitter” ZunZuneo Programme was Covered', The Guardian, April 04, 2014.

Matar, Dina, Bessaiso, Ehab, 'Middle East Media Research' in Ingrid Volkmer, The Handbook of Global Media Research, Oxford: John Wiley \& Sons, 2012.

'Media Development Indicators: a framework for assessing media development', UNESCO, Paris, 2008.

'Supporting Syrian refugees in Lebanon and Jordan', BBC Media Action.

Menocal, Alina, Fritz, Veren, Rakner, Lise, 'Assessing International Democracy Assistance and Lesson Learned: How Can Donors Better Support Democratic Processes?', Overseas Development Institute 12, (2008).

Moeller, Susan D., 'Media Literacy: Citizen Journalists', CIMA, October 1, 2009.

Mosco, Vincent, The Political Economy of Communication, London: SAGE Publications, 2009.

Nelson, Mark, Susman-Pena, Tara, 'Rethinking Media Development: a Report on the Media Map Project', Working Paper by Internews and World Bank Institute, 2012.

Pfeife, Mark, 'Changing the Face(book) of Social Activism', The Huffington Post, July 14, 2009.

Price, Monroe, Davies Noll, Bethany, De Luce, Daniel, 'Mapping Media Assistance', Oxford: University of Oxford, Centre for Socio-Legal Studies, 2002.

Roudi, Farzaneh, 'Youth Population and Employment in the Middle East and North Africa: Opportunity or Challenge?', (paper presented at the United Nations Expert Group Meeting on Adolescents, Youth and Development, New York, 21-22 July 2011). 
Sakr, Naomi, 'Foreign Support for Media Freedom Advocacy in the Arab Mediterranean: Globalization from Above or Below?', Mediterranean Politics 11 (1), 2006.

Sakr, Naomi, 'Media Development and democratization of the Arab Middle East', Global Dialogue 6, Winter/Spring 2004, 98-107.

Schleifer, Abdallah, 'Media Explosion in the Arab World: the PanArab Satellite Broadcasters', Transnational Broadcasting Studies 1, Fall 1998.

Shadid, Anthony, 'Exiles shaping World's Image of Syria's Revolt', The New York Times, April 23, 2011.

Shaery-Eisenlohr, Roshanack, 'From Subjects to Citizens? Civil Society and the Internet in Syria', Middle East Critique 20 (2), Summer 2011, pp. 127-138.

Shaery-Eisenlohr, Roshanack, Cavatorta, Francesco, 'The Internet and Civil Activism in Syria' in, Civil Society in Syria and Iran, Aarts, Paul, Cavatorta. Francesco, Boulder, CO: Lynne Rienner, 2012.

Shah, Hermant, The production of Modernization: Daniel Lerner, Mass Media, and the Passing of Traditional Society, Philadelphia, PA: Temple University Press, 2011.

Stanely, Bruce, 'Crafting the Arab media for peace-building: donors, dialogue and disasters' in Arab Media and Political Renewal, Sakr, Naomi, London: I.B.Tauris, 2007.

Taki, Maha, 'Case study: Syria. Support to media where media freedoms and rights are constrained', $B B C$ Media Action, August 2012.

Whitlock, Craig, 'US secretly backed Syrian opposition groups, cables released by WikiLeaks show', The Washington Post, April 17, 2011.

Wilkins, Karin, 'Considering “Traditional Society in the Middle East: learning Lerner All Over Again!', Middle East Media 6(1), 2001.

Yerkes, Sarah E., Cofman Wittes, Tamara, 'Middle East Partnership Initiative: Progress, Problems, ad Projects', Brookings Research Papers, November 29, 2004.

Note on Contributor. Billie Jeanne Brownlee is an ESRC Postdoctoral Fellow at Institute for Arabic and Islamic Studies at the University of Exeter. Her current postdoctoral research project looks at the micro-politics of refugee crisis management with a specific focus on the case of Lebanon's municipalities. Her PhD research studied the development of the new media and civil society in the Middle East, with a particular attention to Syria. She has published several peer-reviewed articles and book chapters on the Arab uprisings and the politics of new media and she holds a PhD in Middle East Politics at the University of Exeter. Her broader intellectual and academic interest fall within the field of social movements, media politics and studies of displacement. Beside her academic work, she has also been employed as junior officer at the European External Action Service, Crisis Response Division in Brussels.

\section{ACKNOWLEDGMENTS}

The author would like to thank the comments and advice her PhD supervisor, Dr Lise Storm and more broadly a number of people that helped her during the fieldwork and interview process that she would like to maintain anonymous. Moreover, she would like to thank Maziyar Ghiabi for his critical comments and encouragement. 


\section{Notes}

${ }^{1}$ Cf. Colle, 'Threads of Development Communication'.

${ }^{2}$ Cf. Sakr, 'Media Development and democratization of the Arab Middle East'.

3 Cit. Hoffer (1951) in Kedizie, Aragon, 'Coincident Revolutions'.

4 Cf. Kumar, Promoting Independent Media.

5 Cit. Stanely, 'Crafting the Arab media for peace-building'.

6 'What is media for development?', CIMA, http://cima.ned.org/media-development.

7 Nelson, Susman-Pena, 'Rethinking Media Development'.

${ }^{8}$ Cf. UNESCO's index of media development indicators: 'Media Development Indicators'.

9 Cit. in Moeller, 'Media Literacy: Citizen Journalists'.

${ }^{10}$ As opposed to hard power thought of as the use of force and hard weaponry to obtain tangible results. After the mass protests of Iran's post-2009 elections, Western media outlets explained the whole movement in terms of a media phenomenon related to Twitter. This view was so widespread that Twitter was nominated for the Nobel Peace Prize, as if 'Twitter and other social media outlets have become the soft weapons of democracy'. Cf. Pfeife, 'Changing the Face(book) of Social Activism'.

${ }^{11} \mathrm{Cf}$. Shah, The production of Modernization.

${ }^{12}$ See Matar, Bessaiso 'Middle East Media Research'.

${ }_{13}$ Cf. Lerner, Pevsner, The Passing of Traditional Society.

${ }_{14}$ Refer to Wilkins, 'Considering "Traditional Society in the Middle East'.

${ }_{15} \mathrm{Cf}$. Mosco, The Political Economy of Communication.

${ }^{16}$ Cit. Sakr, 'Foreign Support for Media Freedom Advocacy in the Arab Mediterranean'.

${ }_{17}$ Cf. Yerkes, Cofman Wittes, 'Middle East Partnership Initiative'.

${ }^{18}$ See Menocal, Fritz, Rakner, 'Assessing International Democracy Assistance'.

19 Cf. Farzaneh Roudi, 'Youth Population and Employment in the Middle East and North Africa'.

${ }^{20}$ Refer to Taki, 'Case study: Syria'.

${ }^{21}$ Cf. Price, Noll, De Luce, 'Mapping Media Assistance'.

${ }^{22} \mathrm{Cf}$. Kharas, 'Trends and Issues in Development Aid'.

${ }_{23}$ M. Price, 'Mapping Media Assistance', 7-8.

24 Interview with Raniero Leto, via Skype, March 31, 2014.

${ }_{25}$ Cf. Cary, D’Amour, 'US Government Funding for Media'.

${ }^{26}$ S. Yerkes, T. Cofman, 'Middle East Partnership Initiative'. To mention that MEPI was headed at its inception by the then Deputy Assistant Secretary of State (and vice-president daughter) Elizabeth Cheney.

27 Refer to Whitlock, 'US secretly backed Syrian opposition groups'.

28 Interview with Malik al-Abdeh, via Skype, April 05, 2014

29 Juliette Harkin, interviewed via Skype several times between May 2013-March 2014.

${ }^{30}$ The project director was Ibrahim Helal, former editor-in-chief of Al -Jazeera Arabic.

${ }^{31}$ Interview with Maha Taki, via Skype, April 4, 2014.

${ }^{32}$ Cf. 'Supporting Syrian refugees in Lebanon and Jordan' and Bastian Halberg, 'Filling the Information Vacuum for Syrian Refugees'.

33 Interview with Susanne Fischer, at IWPR's office in Beirut, July 30, 2013.

34 Cf. A. Schleifer, 'Media Explosion in the Arab World'.

35 Syrian International Academy for Training and Development, see http://sia-sy.net/sia/index_en.php.

${ }^{36}$ See 'Damascus Bureau', Syria Untold, July 31, 2014.

37 'Arabic Online Academy Boots Cyber-Security', IWPR, January15, 2014.

${ }^{38}$ See Arab Reporters for Investigative Journalism (ARIJ) website: http://en.arij.net/

39 Supported by the Copenhagen-based International Media Support (IMS), the Swedish International

Development Cooperation Agency (SIDA), the Foundation for Open Society, UNESCO, the International

Centre for Journalism (ICFJ) and others, ARIJ has grown in the years and established three units in Jordan, Palestine and Egypt.

40 Interview with Saad Hattar, through Skype, July 18, 2013.

${ }_{41}$ 'With the help of NGO ARIJ, Syrian investigative journalists are revealing underreported social issues that concern the man in the street', ARIJ, June 21, 2010.

42 Interview with Saad Hattar.

43 Bajec, 'How to practise investigative journalism in the Arab region'.

44 Shaery-Eisenlohr, F. Cavatorta, 'The Internet and Civil Activism in Syria'.

45 ZunZuneo was a social network, designed on Twitter's version, initially presenting non-controversial contents like weather, sports, music, which later developed anti-regime content, mobilizing users to organize 
political gathering that would have triggered dissent against the Cuban regime. See, Lewis, Roberts, 'White House denies "Cuban Twitter" ZunZuneo Programme was Covered'.

${ }^{46}$ Cf. Alvarez, 'Radio and TV Marti'.

47 Cit. by Alcorn, Chen, Gardner, Matsumoto, 'Mapping Donor Decision Making on Media Development'.

48 Anthony Shadid, 'Exiles shaping World's Image of Syria's Revolt', The New York Times, April 23, 2011.

49 Interview with Syrian activist Rami Nakhle, through Skype, July O2, 2013.

${ }^{50}$ Cit. Bashar al-Asad by Shaery-Eisenlohr, 'From Subjects to Citizens?'. 